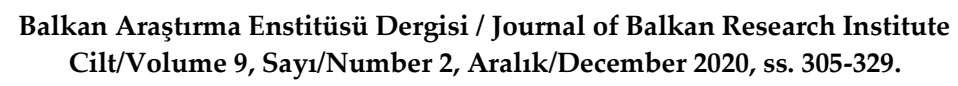

Geliş - Received: 24.02.2020

Kabul - Accepted: 26.09.2020

DOI: $10.30903 /$ Balkan.841076

ARAŞTIRMA MAKALESI - RESEARCH ARTICLE

\title{
RUS KAYNAKLARI IŞIĞINDA BULGARISTAN'IN BAĞIMSIZLIK İLANI
}

\section{Şahin DOĞAN*}

\begin{abstract}
ÖZ
1878 Berlin Antlaşması sonrasında Osmanlı Devleti açısından uluslararası platformda çok önemli değişimler yaşandı. Bu çerçevede en önemli gelişmelerin yaşandığı bölgelerden birisi de İmparatorluğun Balkan topraklarıydı. İmparatorluk topraklarından birer bağımsız devlet olarak ortaya çıkan diğer devletlerden farklı olarak Bulgaristan Osmanlı Devleti'ne bağlı bir Prenslik haline getirildiği gibi Ayastefanos'da belirlenen sınırları da daraltıldı. Bu şekilde başta Bulgarlar olmak üzere uluslararası çevreler açısından Bulgaristan'ın bağımsızlığı meselesi ötelenmiş oldu. 1908-1909 yıllarında Osmanlı iç siyasetindeki gelişmeler Bulgaristan’ın bağımsızlığını ilan etmesi için uygun koşullar yarattı ve bu süreçte Bulgaristan bağımsızlığını ilan etti. İşte bu makale ile bazı Rus kaynakları ışığında bu süreç ele alınmış ve bu kaynakların Bulgaristan'ın Bağımsızlığı süreci araştırmaları ile bu evrede yaşanan uluslararası gelişmelerin açıklanmasına katkıda bulunması hedeflenmiştir.
\end{abstract}

Anahtar Kelimeler: Bulgaristan'ın Bağımsızlık İlanı, Balkanlar, Osmanlı Devleti, Rusya, Rus Kaynakları

\section{THE INDEPENDENCE PROCESS OF BULGARIA IN THE LIGHT OF RUSSIAN SOURCES}

\begin{abstract}
After the Treaty of 1878 Berlin, important changes took place in the international platform for the Ottoman State. Accordingly, one of the region that experienced the most important developments was the Balkan lands of the Empire. Unlike other states that emerged as independent states within the Empire's territory,
\end{abstract}

\footnotetext{
* Doç. Dr., Akdeniz Üniversitesi, Edebiyat Fakültesi Tarih Bölümü, Antalya, ORCID: orcid.org/0000-0001-7443-4176, E-posta: sahindogan@akdeniz.edu.tr
} 


\section{ŞAHIN DOĞAN}

Bulgaria was transformed into a Principality under the Ottoman rule, and its borders determined in Treaty of San Stefano were narrowed. Thus, the issue of independence of Bulgaria was postponed regarding international circles, especially for the Bulgarians. The developments in Ottoman domestic politics between 1908-1909 created favorable conditions for Bulgaria to declare independence and Bulgaria declared its independence in this process. With this article, this process is discussed in the light of some Russian sources. In addition, these sources are intended to contribute to the explanation of the Bulgarian independence process and the international developments at this stage.

Keywords: Declaration of Independence of Bulgaria, Balkans, Ottoman State, Russia, Russian Sources

\section{Giriş}

1877-78 Osmanlı-Rus savaşı sonrası yaşanan uluslararası gelişmeler özellikle Osmanlı İmparatorluğunun Balkan topraklarında çok önemli değişiklikleri beraberinde getirdiği gibi birçok yeni sorunun da ortaya çıkmasına neden oldu. Ayastefanos Antlaşması, Berlin Antlaşması, Sırbistan, Karadağ ve Romanya'nın İmparatorluktan ayrılması, Doğu Rumeli meselesi, Makedonya sorunu, Bosna-Hersek' in işgali, Bulgaristan'ın Bağımsızlık ilanı ve daha sonra Balkan savaşları, büyük göçler gibi siyasi, etnik, sosyal ve uluslararası birçok mesele ortaya çıktı.

Bulgaristan'ın Osmanlı Devleti'nden ayrılarak bağımsızlık ilan etmesi süreci ise Balkanlarda ortaya çıkan bu meseleler içerisinde önemli bir yere sahiptir. Dolayısıyla bu sürecin analiz edilmesi Büyük Devletlerin Balkan politikalarının, Osmanlı Devleti'nin iç ve dış siyasetinin, Balkanlardaki etnik meselelerin, yeni ortaya çıkan Balkan Devletleri aralarındaki sorunların ve genel olarak 19. yüzyılın sonu ve 20. yüzyılın başında yaşanan Balkan meselesinin anlaşılmasına katkı sunmaktadır. ${ }^{1}$

Bulgaristan'ın Osmanlıdan ayrılması ve bağımsızlığını ilan etme süreci birçok bilimsel araştırmaya ${ }^{2}$ konu olmuşsa da Türk tarih literatüründe,

\footnotetext{
${ }^{1}$ Bahsedilen bütün bu hususlarda genel bir kanaat edinmek için, Türkçeye tercüme edilmiş olan Barbara Jelavıch, Balkan Tarihi 18. Ve 19. Yüzyıllar, C. I-II, Çev.: İhsan Durdu, Haşim Koç, Gülçin Koç, Küre Yay., İstanbul 2006 isimli esere bkz.

2 Türkiye'de özellikle Balkanlar, Makedonya Sorunu, Balkanlarda eşkıyalık hareketleri, Balkanlarda milliyetçilik hareketleri, Osmanlı İdaresinde Bulgaristan vb. gibi başlıklar altında birçok değerli çalışmalar yapılmıştır. Bütün bu çalışmalar bir şekilde ele aldığımız konu ile
} 


\section{RUS KAYNAKLARI IŞIĞINDA BULGARISTAN'IN BAĞIMSIZLIK İLANI}

Rus kaynaklarının konuya ilişkin katkısı bulunmamaktadır. ${ }^{3}$ Isşte bu makale ile bazı Rus kaynakları ışığında Bulgaristan'ın bağımsızlık süreci ele alınarak bu boşluk bir nebze doldurulmaya çalışılmıştır. Ancak bir makale ile böyle bir boşluğun doldurulmasının mümkün olmadığı çok açık olduğu gibi, Bulgaristan'ın bağımsızlığına ilişkin çalışmaların başta Rus Dışişleri arşivi olmak üzere Rus kaynakları üzerinden devam ettirilmesinin önemli bir perspektife sahip olduğunu belirtmek isteriz.

\section{Bulgaristan'ın Bağımsızlık İlanı Süreci}

Bilindiği üzere Bulgaristan'ın hukuki statüsünün belirlendiği Berlin Antlaşması'na göre Bulgaristan Osmanlı Devletine vergi veren özerk bir prenslik haline getirildi. Ayrıca yine bu antlaşma ile Bulgaristan'ın daha önce

ilişkili olmakla birlikte böyle bir makalenin sınırlarını aşacağından biz burada “Bulgaristan'ın Bağımsızlığı'nı" konu edinmiş bazı çalışmaları hatırlatmayı uygun bulduk. Bu çalışmalardan bazıları şunlardır: Erhan Vatansever, Bulgar Milliyetçiliğinin Doğuşu ve Bulgaristan'ın Bă̆ımsızlı̆̆ (1841-1908), Trakya Üniversitesi Sosyal Bilimler Enstitüsü, Yayımlanmamış Doktora Tezi, Danışman: Dr. Öğr. Üyesi Sabri Can Sannav, Edirne, 2019; Mahir Aydın, Osmanlı Eyaletinden Üçüncü Bulgar Çarlığına, Kitabevi Yay., İstanbul, 1996; Arzu Taşçan, Bulgaristan'ın Băgımsızlık Sürecinde Kilisenin Fonksiyonel Rolü, Dokuz Eylül Üniversitesi Sosyal Bilimler Enstitüsü, Yayımlanmamış Doktora Tezi, Danışman: Prof. Dr. Mehmet Şeker, İzmir, 2011; Serdar Bay, İkdam ve Tanin Gazetelerine göre Bulgaristan' 'n Bağımsızlı̆gl (19081909), Kafkas Üniversitesi Sosyal Bilimler Enstitüsü, Yayımlanmamış Yüksek Lisans Tezi, Danışman: Doç. Dr. Oktay Kızılkaya, Kars, 2016; Yusuf Sarınay, "Osmanlı Devleti'nin Bulgaristan'ın Bağımsızlığını Tanınması ve Türk-Bulgar İlişkilerinin Gelişmesi”, Uluslararası Osmanlı ve Cumhuriyet Dönemi Türk-Bulgar Ilişkileri Sempozyumu 11-13 Mayıs 2005 Bildiriler Kitabı, Eskişehir, 2005, ss. 133-138; Yasemin Avcı, "Bağımsız Bulgaristan ile Osmanlı Devleti Arasında Modern Diplomasi (1908-1912)", Uluslararası Osmanlı ve Cumhuriyet Dönemi Türk-Bulgar İlişkileri Sempozyumu 11-13 Mayıs 2005 Bildiriler Kitabı, Eskişehir, 2005, ss. 291-297; Erol Çetin, Bulgaristan Prensliği ile Osmanlı Imparatorluğu Arasındaki Siyasi İlişkiler (1878-1908), İstanbul Üniversitesi Sosyal Bilimler Enstitüsü, Yayımlanmamış Doktora Tezi, Danışman: Prof. Dr. Toktamış Ateş, İstanbul, 2003; Ayrıca Bulgaristan'ın bağımsızlığı sürecinde etkin bir rol oynayan Rusya'nın 19. Yüzyıl boyunca (Berlin Antlaşması'na kadar olan dönem) bu hususta izlediği siyasetin irdelendiği Serap Toprak, “Bulgaristan'ın Bağımsızlığında Rusya'nın Rolü”, History Studies Uluslararası Tarih Araştırmaları Dergisi, Cilt V, Sayı 6 [Balkan Savaşları Özel Sayıs1], Samsun, 2013, s. 131147. İsimli çalışma da zikredilebilir.

3 Berlin Antlaşması sonrası Osmanlı Devleti, yeni ortaya çıkan Balkan Devletleri ve Bulgaristan'ın özellikle askeri stratejileri ve askeri güçlerine ilişkin bilgiler açısından önem arz eden Rus Genelkurmay belgelerinden derlenmiş olan İstanbul Rus askeri ataşesinin raporlarının Türkçe tercümelerinin yayımlandığı Rus Genelkurmay Belgelerinde II.Abdülhamid ve Ordusu, (Yayına Hazırlayanlar: Mikhail Bashanov-İlyas Kemaloğlu), Zeytinburnu Belediyesi Kültür Yayınları, İstanbul 2018, isimli eseri burada zikretmemiz gerekir. 


\section{ŞAHIN DOĞAN}

Ayastefanos Antlaşmasında belirlenen sınırları oldukça daraltıldı. Nitekim aynı antlaşma ile Doğu Rumeli Vilayeti Osmanlıya bağlı özerk bir bölge haline getirildiği gibi Makedonya ise reformlar yapılması koşulu ile Osmanlı Devleti'ne birakıldı. ${ }^{4}$

Berlin Antlaşması neticesinde Bulgaristan'ın Ayastefanos Antlaşmasına göre 172 bin km2 olan toprakları 64 bin $\mathrm{km}^{2}$ 'ye düşürülmüştü. Ayrıca Bulgaristan tam bağımsız bir devlet olamamıştı. Bu nedenden ötürü Berlin Antlaşması'ndan sonra Bulgaristan'ın dış politikadaki en önemli hedefi Osmanlı Devleti'nden ayrılarak tam bağımsız olmak ve bundan sonra Berlin Antlaşması gereği Prenslik dışında kalan bütün Bulgarları bir çatı altında toplayarak milli birliğini sağlamak yönünde şekillendi. ${ }^{5} \mathrm{Bu}$ durum Balkanlarda yeni sorunların ortaya çıkması için de uygun bir zemin hazırlamış oldu ve özellikle Makedonya meselesi içinden çıkılmaz bir hal almaya başladı. $^{6}$

Balkanlardaki bu gelişmelerin seyri içerisinde 20. yüzyılın başında Bulgaristan'ın uluslararası arenadaki konumu güçlendi. Rusya Bulgaristan'da Coburg Hanedanlığını tanıdı ve bu durum Bulgaristan'ın diğer ülkeler ile olan ekonomik ve siyasi ilişkilerinin gelişmesinde önemli bir rol oynadı. Her ne kadar Osmanlı Devleti'ne bağlı bir statüsü olsa da Bulgaristan'ın Büyük Devletlerin başkentlerinde ve komşu Balkan Devletlerinde diplomatik

\footnotetext{
${ }^{4}$ Sarınay, a.g.m., s. 4.

${ }^{5}$ Çetin, a.g.t., s. 14.

6 Makedonya sorunu hakkında Rusya'da birçok çalışma olmakla birlikte yakın zamanda yapılan çalışmalardan bazıları şunlardır: Aleksandr Nikolayeviç Skvoznikov, Makedonskiy Vopros vo Vneşney Politike Rossii v Naçale XX veka (1903-1908), Samarskiy GPU Avtoreferat, Nauçniy Rukovoditel: Anşakov Yuriy Petroviç, Samara, 2006. (Bu tezde özellikle Rusça, Bulgarca, İngilizce kaynaklar detaylı bir şekilde irdelenmiş ve literatür verilmiştir); A. N. Skvoznikov, "Rossiyskaya Diplomatiya o Putyah Reşeniya Makedonskoy Problemı v Kontse XIX- Naçale XX Veka", İzvestiya Somarskogo Nauçnogo Sentra RAN, T.12, No:2, Samara, 2010, ss.82-86.; A. N. Skvoznikov, Makedonskiy Vopros v Naçele XX Veka i Rossiyskaya Obşestvennost", İzestiya Somarskogo Nauçnogo Sentra RAN, T. 11, No: 2, Samara, 2009, ss.70-76. ; Türkiye'de de bu konuya ilișkin değerli birçok çalıșma yapılmıștır bunlardan bazılarını burada zikretmek gerekirse: Fikret Adanır, Makedonya Sorunu, Tarih vakfı Yurt Yay., İstanbul, 1996.; Gül Tokay, Makedonya Sorunu ve Jön Türk Ihtilalinin Kökenleri 1903-1908, Afa yay. İstanbul, 1995.; Mehmet Hacısalihoğlu, "İttihatçlar ve Makedonya İhtilal Komiteleri: İttihad ve Terakki Hükümetinin Başlamasına Kadar İlişkiler, Pazarlıklar ve Sonuçları", İstanbul Üniversitesi Edebiyat Fakültesi Tarih Dergisi, No: 38, İstanbul, 2002, ss. 101-117; Meltem Begüm Saatçi, Makedonya Sorunu (1903-1913), Akdeniz Üniversitesi. Sosyal Bilimler Enstitüsü, Yayımlanmamış Doktora Tezi, Danışman: Prof. Dr. İsrafil Kurtcephe, Antalya, 2004. vd.
} 


\section{RUS KAYNAKLARI IŞIĞINDA BULGARISTAN'IN BAĞIMSIZLIK ILANI}

temsilcilikleri bulunduğunu belirtmek gerekir. Nitekim bu dönemde Bulgaristan'ın dış politikası gittikçe aktif bir hal aldı. ${ }^{7}$

Bulgaristan Osmanlı Devleti ile ilişkilerini bağımsız bir devlet gibi sürdürmekteydi: $\mathrm{Bu}$ süreçte Bulgaristan diğer devletlerden borç para alıp savaş gemileri sipariş ettiği gibi, ayrıca 1880 senesinde Bulgar parasını tedavüle çıarıp kullanmaya başlamış ve Türkçe resmiyetten kaldırılmıştı. ${ }^{8}$

$\mathrm{Bu}$ dönemde Bulgaristan iktisadi bakımdan Fransa, İngiltere ve Avusturya-Macaristan sermayesine önemli düzeyde bağımlı hale gelmişti. Ancak henüz Bulgaristan'da hangi büyük devletin hakim duruma geleceği açıklığa kavuşmaması nedeniyle Bulgaristan'da hâkim güç olmak için Büyük Devletler arasında önemli bir rekabet vardı. Bulgaristan da Büyük Devletlerin bu politikaları karşısında istikrarlı bir siyaset izleyememekteydi. Zira Bulgaristan'da değişen iktidarlara göre dış siyaset şekillenmekteydi: Örneğin: Liberaller (radoslavistskaya) ve Halk Liberal Partisi (Stambolcüler) (Ferdinand'ın başında olduğu saray bu partilere yakındı) AvusturyaMacaristan'a yakındılar; Tarım-Finans (agrarna-finans) Halk Partisi ve aynı zamanda Terakkiciler (progresistler) ve Demokratlar'ın ise Rusya, Fransa ve İngiltere ile yakın ilişkileri bulunmaktaydı. ${ }^{9}$

Bulgar Hükümeti özellikle 1903 yılı itibari ile silahlanmaya başladı. Hükümet, ordu için büyük miktarlarda silah ve mühimmat satın almaktaydı. Ayrıca bu dönemde ülkede patlayıcı üretiminin geliştirilmesi için harekete geçildi. Bu bağlamda 1903-1908 yılları arasında Bulgaristan'ın sadece askeri giderlerine 99,3 milyon leva ayrılmıştı. Bu çerçevede Bulgaristan'a sıkça Almanya ve Avusturya-Macaristan'dan eski silah ve mühimmat gelmekteydi. Bulgaristan'ın bu şekilde silahlanması için büyük miktarlarda para gerekliydi ve iç sermaye bunun için yeterli değildi. Bu nedenle Bulgaristan büyük borçlar yapmak zorunda kaldı. Nitekim ülkenin 1902 yılında 252,9 milyon leva olan borcu 1907 senesinde 406,6 milyon leva'ya ulaşmıştı. Askeri giderler nedeniyle yapılan büyük borçlanma Malinov hükümeti döneminde de devam etti. Demokratların yönetimi sırasında askeri giderler 178,5 milyon leva gibi çok büyük miktarlara ulaşmıştı ve 1909 senesinde yeniden Fransız

\footnotetext{
${ }^{7}$ İ. V. Kozmenko ve V. D. Konobeyev, “Aktivizisatsiya vneşney Politiki Bolgarskoy burjuazii v naçale XX v.", İstoriya Bolgarii, AN SSSR, T.I, Moskva 1954, s. 473.

8 Avc1, a.g.m., s. 292.

${ }^{9}$ Kozmenko ve Konobeyev, a.g.m., s. 473.
} 


\section{ŞAHIN DOĞAN}

bankasından 182 milyon leva kredi alındı. Hâlbuki Fransız bankasından 1907 senesinde 145 milyon leva kredi alınmıştı. ${ }^{10}$

$\mathrm{Bu}$ dönemde ülkede yoğun bir şekilde stratejik önemi haiz demir yolları inşa edilmekteydi ve 1908 yılında askeri birliklerin sevkiyatını kolaylaştıracak olan Transbalkan demir yolu tamamlanmıştı. Bulgaristan'da askeri hazırlıkların tamamlanması ile Bulgar yönetimi, Ülkenin Osmanlı Devleti ile vasal ilişkinin kalıntılarından kurtulmak isteği iyice açı̆̆a çıkmıştı. Zira yukarıda belirtildiği üzere Bulgaristan'ın Osmanlı Devleti'ne bu bağlılığı çerçevesinde Güney Bulgaristan'daki demir yollarının büyük bir kısmı Osmanlı Devleti'ne ait idi ve bu demir yolları kapitülasyon rejimine tabiydi. Ayrıca Bulgaristan Osmanlı Devleti'ne yıllık vergi vermek durumundaydı. ${ }^{11}$

1908 yılında Osmanlı Devleti'nde yaşanan siyasi kriz neticesinde ortaya çıkan uluslararası konjonktür Bulgaristan için elverişli bir ortam yarattı. ${ }^{12} 1908$ yılı Temmuz ayında yaşanan Jön Türk İhtilali, özellikle Balkanlardaki durumun değişmesi ve Büyük Devletlerin Osmanlı Devleti ile ilişkileri açısından uluslararası platformda güç dengelerinin değişiminde oldukça etkili oldu. Zira Büyük Devletler Berlin Antlaşmasına göre Osmanlı Devletinin bütünlüğünün korunması için bir garantör durumundaydılar. ${ }^{13}$

Osmanlı İmparatorluğunun bir iç meselesi olan 23 Temmuz İhtilali uluslararası ilişkiler alanında da büyük bir etki yarattı. Özellikle Büyük Devletler olmak üzere birçok devlet İmparatorluğun yeniden şekillenen iç siyasal hayatının ne gibi sonuçlar doğuracağı ve kendilerini nasıl etkileyeceğini ve bu durumdan Doğu sorunu çerçevesinde en karlı nasıl çıkabileceklerinin hesabıyla gelişmeleri oldukça yakından takip etmişlerdir. Nitekim Osmanlı İmparatorluğu'nun kısa bir zaman önce bir parçası olan Balkan Devletleri de bu gelişmeleri büyük bir ilgi ile takip etmek durumunda kalmışlardı. Zira başlangıçta İmparatorluktaki yeni rejimin ne getireceği bir muamma idi.

Bulgaristan'da da Malinov Kabinesi ve Ferdinand Jön Türk İhtilali'nden sonra ani bir şekilde değişen uluslararası koşullardan yararlanarak başka bir deyişle Büyük Devletlerin çoğunluğunun Osmanlı

\footnotetext{
10 "Ayn1 yerde", s. 476.

11 "Aynı yerde".

12 "Aynı yerde".

${ }^{13}$ N.N. Çervenkov ve G. D. Şkundin, "Provozglaşeniye Nizavisimosti i obyavleniye Bolgarii Çarsrtvam”, Bolgariya v XX Veke Oçerki Politiçeskoy Ístorii, Nauka, Moskva 2003, s. 29.
} 


\section{RUS KAYNAKLARI IŞIĞINDA BULGARISTAN'IN BAĞIMSIZLIK ILANI}

Devleti ile ilişkilerinin soğumasından faydalanmak ve Bulgaristan'ın İmparatorluğa vasal bağlılı̆̆ını kaldırmak için harekete geçmişlerdi. ${ }^{14}$

Rusya'nın Bulgaristan Askeri ataşesi Albay Leontiev 21(8) Ağustos 1908 tarihinde kaleme aldığı raporda Osmanlı Devleti içerisinde yaşanan Jön Türk İhtilali'nin Bulgarlar üzerindeki etkisi hakkında bilgiler verirken, Bulgarların aktif bir şekilde gösteriler yapmaya başlayabileceğini bildirmekte ve Bulgarlar için Osmanlı Devleti içerisindeki Temmuz olaylarının üzerinden yaklaşık bir ay sonra ani etkilerinin geçmekte olduğunu ve gitgide Bulgarların zihninde Osmanlı'da şu anda yaşanan olayların karmaşık ve zorlu sonuçlarının şekillenmeye başladığını ifade etmekteydi. Mamafih Bulgaristan'da hükümet ve kamuoyu hala beklemede ve yeni ihtilale karş1 tutumları yeterince belirmemişti. Ancak, Albay Leontiev'e göre Bulgarların tutumu sadece düşmanca olabilirdi. Nitekim, ona göre bu konuda, Jön Türk programının eğitim kurumlarının millileştirilmesi (Türkçeleştirilmesi manasında) kısmı hakkında konuşmak zorunda kalan hükümet veya en azından Sofya gazetelerinin tutumundan bile tahmin yapılabilirdi. Zira Bulgar gazeteleri bir ağızdan, bu önlemlerin sadece birinin uygulanmasının bile bütün Bulgarları birleşmeye, Bulgar milletini ve kültürünü savunma mücadelesi vermeye zorlayacağını yazmaktayd ${ }_{1}{ }^{15}$ Jön Türklerin devlet okullarında bütün derslerin devlet dili ile öğretilmesi talimatını vermeleri Bulgarlar arasında sorunların doğmasına neden olmuştu. ${ }^{16}$

Bulgarlar sadece bu sorunu bir tehdit olarak görmüyorlardı aynı zamanda onların açısından "Büyük Bulgaristan'ın birleşme olasılı̆̆ 1 da tehlikede idi. Bu sorun, Türklerden daha çok, geçmişte de aralarında Bulgar aleyhtarı akımların görüldüğü Makedonyalı Bulgarların kendilerinden kaynaklanıyordu. Nitekim "Makedonya Makedonyalılar için" oradaki aydınlar arasında çok yaygın olan bir kavramdı. ${ }^{17}$

Bulgar yetkililer, diplomatlarla özel konuşmalarında yakın gelecek için endişelerini gizlemiyorlardı. Onların görüşüne göre, Doğu Sorununun

\footnotetext{
${ }^{14}$ G.G. Litavrin, Kratkaya İstoriya Bolgarii s Drevneyşih Vremen do Naşih Dney, İzd: Nauka, Moskva 1987, s. 285.; Çervenkov - Şkundin, a.g.m., s. 30.

${ }^{15}$ Raport voennogo agenta v Bolgarii ot 21(8) avgusta $1908 \mathrm{~g}$. No:143. Der.: PAPOV, A. “Turetskaya Revolutsiya 1908-1909”, Krasniy Arhiv, T. 1 (44), Moskva 1931, s. 10-11, (Krasnıy Arhiv'de yayımlanmış olan belgeler dipnotlarda daha açıklayıcı olması nedeniyle belge isimleri ve numaraları ile verilmiştir.)

${ }^{16}$ L. Galberştadt, "İnostrannaya Politika”, Russkaya Mısl, Eylül 1908, s. 205.

${ }^{17}$ Raport voennogo agenta v Bolgarii ot 21(8) avgusta 1908 g. N-143.
} 


\section{ŞAHIN DOĞAN}

nihai çözümü doruğa ulaşmak üzere ve bütün gelecekleri şu anda nasıl bir tutum izleyeceklerine bağlı olacaktı. Aynı zamanda, Leontiev'e göre, sorunun barışçıl ve dolayısıyla genel çıkarlar açısından tercih edilen çözümü, Bulgarlar için çözüm kararının en elverişsizi olabilirdi. Zira böyle giderse, 1908 yılı sonbaharında çok büyük olaylar yaşanabilirdi. Çünkü Bulgarların bilinci bu yönde güçlenirse, onları silaha sarılmaya ve ölüm kalım mücadelesi için her şeylerini ortaya koymaya küçük bir bahane yeterli olacaktı. ${ }^{18}$

Leontiev'e göre bu sonuca varan tek kişi kendisi değildi. Zira, Rusya'nın Sofya Büyükelçisi de yaklaşık olarak aynı düşüncede olduğu gibi böyle bir görüş yabancı diplomatlar arasında da hâkimdi; o günlerde Türkiye'den yeni dönmüş - görünüşe göre oradan belirsiz bir izlenim almışolan Fransız elçi, Milyukov ile olan konuşmasını anlatırken sözlerini şu şekilde bitirmişti: “Evet, bir devrimin ve üstelik de Türkiye'de, büyük kargaşa olmadan cereyan etmesine inanmak zor. Bulgaristan'a gelince, şimdilik burada her şey sakin görünüyor, ancak bu sakinlik yanıltıcl: Ístanbul'daki en ufak bir karmaşa veya Makedonya'daki bir klvılcım, Bulgarları faal eylemlere yönelmeye mecbur edebilir ve o zaman da durdurulmalarl çok zorlaşır". ${ }^{19}$

Leontiev, Rusya açısından bu durumun bir firsat olduğunu söylemekle birlikte bu defa kendilerince Bulgarlara yapılan tüm önerilerin ve uyarıların tamamen yararsız olacağını, hatta belirli koşullar altında zararlı olacağını, öyle ki, Bulgarları başka yönlerden destek aramaya zorlayabileceğini düşünmekteydi. Nitekim, Rus ataşeye göre Bulgarların bu desteği bulmaları o kadar da zor olmayacaktı. Zira, Bosna-Hersek'in geleceği için endişe duyan Avusturya Bulgaristan'a destek veren ilk devlet olacaktı. ${ }^{20}$

Leontiev'e göre Bulgaristan'da hava yavaş-yavaş gerginleşiyor ve böyle giderse bir firtınaya dönüşecekti. Mesele sadece felaketin ne zaman yaşanabileceğinin öngörülmesindeydi. Zira, Bulgaristan'da 11 Ağustos 1908 tarihinde Şipka olayı yıldönümü vesilesiyle bir anma töreni düzenlenmiş ve ardından "Çar Kurtarıcı" anıtına bir çelenk konulmuştu. Anma töreninden sonra, katedraldeki rahip "yaklaşan zor zamanlar" nedeniyle, Bulgarlara ortak çıkarlar adına bir araya gelmeye ve "Büyük Bulgaristan" düşmanlarına karşı mücadeleye hazırlanmalarına çağrıda bulunan kısa bir konuşma yapmıştı;

\footnotetext{
${ }^{18}$ Raport voennogo agenta v Bolgarii ot 21(8) avgusta 1908 g. N-143.

${ }^{19}$ Raport voennogo agenta v Bolgarii ot 21(8) avgusta 1908 g. N-143.

${ }^{20}$ Raport voennogo agenta v Bolgarii ot 21(8) avgusta 1908 g. N-143.
} 


\section{RUS KAYNAKLARI IŞIĞINDA BULGARISTAN'IN BAĞIMSIZLIK ILANI}

benzer konular, anıtın önünde toplanan kalabalığa hitaben, eski bir gönüllü olan Karastoyanov tarafindan da söylendi. Her iki konuşma çok temkinli bir üslupta yapılmıştı ancak dönemin ruhunu anlatmak için büyük bir anlam içermekteydi. ${ }^{21}$ Anlaşıldığ üzere Jön Türk İhtilali sonrasında Bulgarlar için her ne kadar bir belirsizlik yaşansa da bağımsılılı ilanı için gerekli gelişmeler için uygun bir ortam doğmuştu.

Mevcut durumdan faydalanarak Bulgaristan'ın bağımsızlığını ilk kez somut olarak ifade eden kişi İstanbul'da diplomatik temsilci olarak bulunan Bulgar Diplomat İvan St. Geşov oldu. Daha 1 Ağustos 1908 tarihinde Dışişleri Bakanı Paprikov'a yazmış olduğu gizli özel bir mektubunda bu İhtilalin Bulgaristan açısından olumsuz sonuçlar doğuracağı tespitinde bulunmaktaydi. Zira ona göre bu ihtilal neticesinde Makedonya'nın Bulgaristan'a bağlanmasından uzaklaşılmaktaydı. Bununla birlikte Geşov sözlerine şu şekilde devam ediyor: "E Ĕger Jön Türk İhtilalinden bir şeyler kaybedeceksek o vakit bu bir şekilde tazmin edilmelidir. Bu bugün için Bulgaristan'ın tam bağımsızlığı dışında başka bir şey olamaz. Nitekim kararlı bir giriş̧imle Bulgaristan'ın bağımsızlı̆̆ını ilan edip süresiz olarak Osmanlı Imparatorluğu ile olan ilişkimizi koparmak mevcut durumda neden olmasin". 22

Fakat Geşov'un bu teklifi Sofya'da zamansız olarak değerlendirildi. $\mathrm{Bu}$ teklif hakkında 7 Ağustos'da Avusturya-Macaristan'da bulunan Ferdinand'a Paprikov şunları yazarak bu adımın tehlikeli olabileceğini bildirmekteydi: "Böyle bir adımın çok risk barındırdı̆̆ ve tehlikeli olduğu düşüncesindeyim. Özellikle şimdi biz paratoner olmallyız. Görünüyor ki biraz sonra bunu yapmak daha kolay ve tehlikesiz olacaktır." Bu şekilde Hükümet, gelişmeleri beklemeyi ve Makedonya'da anayasal kulüpler olarak adlandırılan birimlerin oluşturulması kararını almıştı. ${ }^{23}$

19 Ağustos'ta Osmanlı Devleti'nde siyasi durum daha istikrarlı hale gelince, Paprikov Ferdinand'a: “Bizim yakın dönem amacımız Bulgaristan'ın bağımsızlığı ve Makedonya'nın yönetiminde bazı özel haklarımızın (örneğin: bazı toplulukların özerkliği, eğitim işlerinin özerkliği vb) korunması olmalıdır." şeklindeki düşüncelerini yazdı. İki gün sonra Malinov da aynı

\footnotetext{
${ }^{21}$ Raport voennogo agenta v Bolgarii ot 21(8) avgusta 1908 g. N-143.

${ }^{22}$ Çervenkov ve Şkundin, a.g.m., s. 30.

23 "Aynı yerde".
} 


\section{ŞAHIN DOĞAN}

şekilde Knez'e bir mektup yazarak Bulgaristan'ın bağımsızlı̆̆ının ilan edilmesi için zamanın geldiğini belirtti. ${ }^{24}$

Knez bu mektubu alınca diplomatik bazı girişimlerde bulundu. Ancak Ferdinand oldukça dikkatli ve kurnaz bir diplomattı. Aslında Ferdinand bağımsızlık fikrine destek vererek, bu aksiyonun engellenmesi durumunda kendi açısından bir mazereti olması için bir süreliğine sahnenin önüne çıkmak istememişti. Bu durum onun bağımsızlık ilanının tarihinin belirlenmesindeki kararsızlığı ve kesin olmayan pozisyonu ile açıklanabilirdi. ${ }^{25}$

$\mathrm{Bu}$ arada Türk-Bulgar ilişkileri belirsizliğini korumaktaydı. İstanbul'da bulunan Bulgaristan'ın diplomatik temsilcisi Geşov'un bakanlığın diplomatlara verdiği yemeğe yazılı olarak davet edilmemesi olayı her iki taraf için de bir sorun haline geldi. Bu olayın altında yatan siyasi neden çok açıktı. Zira Jön Türkler görünüşe göre Bulgaristan'ın Osmanlıya bağlı olmas1 teorisini korumak niyetindeydiler. Sofya'da ise gazete haberlerine bakılırsa Büyük Bulgaristan'1 yaratma ümitlerini yıkmış olan yeni rejime "düşmanca" bir tavır alınmıştı. ${ }^{26}$

Yukarıda belirtildiği üzere Bulgaristan'nın İstanbul'daki diplomatik temsilcisi Geşov 13 Eylül 1908 günü, geleneksel bir toplantıya Osmanlıya bağlı bir prenslik olması nedeniyle davet edilmedi. Bu nedenle Bulgaristan bu duruma oldukça sert bir tavır alarak 18 Eylül günü Geşov'u Sofya'ya geri çağırdı. Bu olaydan ${ }^{27} 6$ gün sonra ise Malinov, Paprikov'a çektiği bir telgrafta Geşov ile ilgili yaşanan bu olayın Bulgaristan'ın bağımsızlığını gündeme getirmek için mükemmel bir gelişme olduğunu bildirdi. Bulgaristan ile Osmanlı Devleti arasında bir kriz başlamışt1 ${ }^{28}$ ve Bulgaristan bu durumu bağımsızlık ilanı için bir firsat olarak kullanacaktı. ${ }^{29}$

Osmanl1 Devletine ait Belova-Svilengrad demiryolu hattındaki ayaklanmadan faydalanarak Bulgar yönetimi 19 Eylül 1908 tarihinde buranın

\footnotetext{
24 "Aynı yerde".

25 "Ayn1 yerde", s. 30-31.

${ }^{26}$ L. Galberştadt, "İnostrannaya Politika”, Russkaya Mısl, Eylül 1908, s. 205.

${ }^{27} \mathrm{Bu}$ olay ile ilgili daha geniş bilgi için Bkz.: Enver Ziya Karal, Osmanlı Tarihi (İkinci Meşrutiyet ve Birinci Dünya Savaşı), C. V, TTK Yay. (basım yeri ve yılı belirtilmemiş), s. 226. ${ }^{28}$ Çervenkov ve Şkundin, a.g.m., s. 31.

29 İ. V. Kozmenko, V. D. Konobeyev, "Aktivizisatsiya vneşney Politiki Bolgarskoy Burjuazii v naçale XX v.”, Ístoriya Bolgarii, AN SSSR, T.I, Moskva 1954, s. 477.; Bu gelişme hakkında daha geniş bilgi için bkz.: Mithat Aydın, "Bulgaristan Yol Ayrımında: İvan S. Geşov Meselesi”, Belleten, C. 7, S. 280, Ankara 2013, ss. 1071-1102.
} 


\section{RUS KAYNAKLARI IŞIĞINDA BULGARISTAN'IN BAĞIMSIZLIK ILANI}

kontrolünü ele geçirdi. Bu durum Osmanlı Devleti'nin yanında özellikle Alman ve Avusturya olmak üzere buraya sermaye yatırmış olan batılı bankaların çıkarlarına da dokununca kriz daha da derinleşti. ${ }^{30}$

$\mathrm{Bu}$ durumda Bulgar hükümeti, Bulgaristan'ın bağımsızlı̆g 1 meselesinde Berlin Antlaşmasını tek taraflı bozmamak için diplomatik girişimlere başlama kararı aldı. Ferdinand özellikle Viyana'nın aldığı pozisyona dikkat ediyordu. Zira bu ilgi boş değildi. Nitekim Viyana da Berlin Antlaşmasını bozma yollarını denemekte ve böylece işgal edilmiş olan Bosna ve Hersek topraklarını ele geçirmek istemekteydi. Bu nedenle Bulgaristan, Avusturya- Macaristan'1 bu krizi destekleyen bir güç olarak görüyor ve Berlin Antlaşmasını imzalamış bir ülke olarak Avusturya- Macaristan'ın bu krizde yer almasından faydalanmaya çalışıyordu. ${ }^{31}$

Bulgarların bağımsızlık ilan etmesini Fransız hükümeti de desteklemekteydi. Nitekim Fransa, Fas nedeni ile sorunlar yaşamakta ve dünya diplomasisinin bakışını yeni bir kriz ile Doğu'ya yönlendirmeye çalışmakta idi. Rusya ise Bulgaristan'ın bağımsızlık statüsüne itiraz etmiyordu. $^{32}$

Bulgar hükümeti, artık karar verilen bağımsızlık meselesini bir an evvel halletmek için gelişmeleri hızlandırdı. Knez Ferdinand Viyana'da iken 29 Eylül 1908 tarihinde Bakanlar Kurulu, Malinov'un bulunmadığı bir toplantıda biran evvel bağımsızlığın ilan edilmesi kararını aldı. Ancak Knez alınan bu kararın ertelenmesini sağladı. Bakanlar Ferdinand'a birçok telgraf çektiler ise de o, bu telgraflara cevap vermedi. Zira Ferdinand, Viyana'nın desteğini almaya çabalamaktaydı. Ancak Viyana, Güney Bulgaristan'daki demir yollarının Osmanlı Devleti'ne geri verilmesini istemekteydi. Ferdinand ise bunu kabul etmeye hazırdı. Ancak kabine bu meselede oldukça katı bir tavır almıştı ve hatta Malinov'u çekilmekle tehdit etmişti. Bu şekilde Bulgar hükümeti daha sonraki gelişmelerin sorumluluğunu tamamen üzerine almış oluyordu. ${ }^{33}$

Sonunda Avusturya İmparatoru Ferdinand İosif'in kişisel desteğini alan Ferdinand 3 Ekim tarihinde Bulgaristan'a Rusçuk üzerinden döneceğini haber verdi. Buraya aynı zamanda bakanlar da hareket ettiler. Bakanların

\footnotetext{
${ }^{30}$ Çervenkov ve Şkundin, a.g.m., s. 31.

31 "Ayn1 yerde".

32 "Ayn1 yerde".

33 “Ayn1 yerde", s. 32.
} 


\section{ŞAHIN DOĞAN}

Ferdinand'ın aldığı karar hakkında bilgileri henüz yoktu. Sonunda "Han Krum" yatında bir toplantı gerçekleştirildi. Knez, Malinov'a seslenerek şunlar1 söyledi: "Malinov Bey efendi, sizin için, benim için ve bütün Bulgar halkn için uzun bir süredir beklenen gün geldi. Karpatlar'da sizinle birlikte aldığımı kararı şimdi uygulama zamanı geldi." ${ }^{34}$

5 Ekim 1908 günü, Viyana'nın Bosna-Hersek'i ilhakı arifesinde Veliko-Tırnova'da Kırk Azizler Kilisesinde yapılan bir tören ile Bulgaristan'ın bağımsızlığ ilan edildi. ${ }^{35}$

Malinov bağımsızlık bildirgesini okudu. Ülke çarlık, Ferdinand ise Bulgarların çarı unvanını aldı. Tırnova metropoliti Ferdinand'a çar tacını giydirdi. Ancak, Bulgaristan yöneticileri bu durumu bir son olarak değerlendirmiyor ancak Ayatefanos'da belirlenmiş olan birleşik Bulgar sınırları için bir adım olarak görüyorlardı. ${ }^{36}$

$\mathrm{Bu}$ gelişmenin ardından Malinov hükümeti Büyük Devletlere gönderdiği bir telgraf ile Bulgaristan'ın Balkanlar'da barışın bozulmaması için gereken her şeyi yapacağını bildirdi. Ancak, eğer şartlar barışı bozar ise "Bulgar milleti tek vücud olup kendi haklarını koruyacaktı. Ferdinand ise 15 Ekim 1908 tarihli Meclis toplantısında yaptığı konuşmasında kurtarıcı Rusya 'nın ve diğer Büyük Devletlerin desteğini ümit ettiğini ifade etti. Ayrıca bu konuşmasında Ferdinand 6 Ekim günü Bosna-Hersek'i işgal etmiş olan Avusturya hükümeti ile kendi eylemlerinin uyum içerisinde olduğunun altını çizdi. ${ }^{37}$

Bulgaristan'ın bağımsızlığını ilan edip Ferdinand'ın Bulgarların çarı unvanını alması ile onun ülkedeki siyasi gücü de arttı. Ferdinand'ın hem iç politikada hem de diş politikadaki etkisi zamanla artarak devam etti. Özellikle Bulgar dış politikası Ferdinand'ın elinde toplanmıştı. Öyle ki sıkça gizli diplomatik belgeler devlet arşivinde değil onun kişisel arşivinde bulunuyordu. ${ }^{38}$

Bulgaristan'ın bağımsılılı̆ının ilanı açıkça Berlin Kongresi ile oluşan siyasi sisteme aykırıydı ve bu nedenle bazı Büyük Devletlerin başkentlerinde

\footnotetext{
${ }^{34}$ Çervenkov ve Şkundin, a.g.m., s. 32.

35 "Aynı yerde".

36 "Aynı yerde".

${ }^{37}$ Kozmenko ve Konobeyev, a.g.m., s. 477.

${ }^{38}$ G.G. Litavrin, Kratkaya İstoriya Bolgarii s Drevneyşih Vremen do Naşih Dney, İzd: Nauka, Moskva 1987, s. 286-287.
} 


\section{RUS KAYNAKLARI IŞIĞINDA BULGARISTAN'IN BAĞIMSIZLIK ILANI}

bu durum temkinle karşıland $1 .{ }^{39}$ Zira Rusya bu durumun Balkanlardaki ortamı daha da zor bir aşamaya getirebileceği düşüncesiyle bu sorunu zamana biraktı. Almanya ve Avusturya-Macaristan ise her ne kadar Ferdinand'a sempati duysalar da onu çar olarak tanımakta acele etmediler. Bu ülkelerin demir yolları üzerinden iktisadi çıkarları bunu gerektiriyordu. ${ }^{40}$

İngiltere hariciyesi ise iki hususta endişe duymaktayd. Birincisi Bulgaristan ve Avusturya-Macaristan'ın eşzamanlı hareket etmesi, ikincisi ise Genç Türk idarecilerinin kararsızlığıydı. Berlin Antlaşmasının maddelerinin altında imzaları olan bütün devletlerin rızası olmadan revize edilmesi onu bozan Büyük Devletlerin lehine güç dengelerini değiştirecekti. Viyana ve Sofya'nın bu mesele üzerinde anlaşmaları, Balkan meselelerinde en önemli rolü oynayan devletlerden biri olan Bulgaristan'1 AvusturyaMacaristan tarafına sürükleyecekti. Diğer taraftan İngiliz hariciyesinin Bulgaristan'ın bağımsızlık ilan etmesiyle ilgili siyasetinin temellerinden biri de Rus-İngiliz ilişkilerinde yatmaktaydı. İlk önce her iki ülke de Bulgaristan'ın uluslararası statüsünün değiştirilmesine karşı olduklarını deklare ettiler. İngiltere Rusya'nın böyle bir durumda bütün sorumluluğun Bulgar hükümetinde olduğu yönündeki açıklamasını destekledi. Daha sonra ise Londra, Paris ve Petersburg Bulgaristan'ın bağımsızlığını resmi olarak ancak Bulgar ve Türk tarafların tazminat hususunda anlaşmaları durumunda kabul edeceklerini açıkladılar. ${ }^{41}$

Ancak bu arada Bulgaristan'daki Britanya diplomatik ataşesi C. Byukenen ve onun Fransız meslektaşı M. Paleolog Sofya'dan çektikleri telgraflarda kendi hükümetlerine bir an evvel Bulgaristan'ın bağımsızlığının tanınması gerektiğini yazmaktaydılar. ${ }^{42}$

Osmanlı Devleti, Avusturya'nın Bosna -Hersek'i işgalini tanımadığ 1 gibi Bulgaristan'ın bağımsızlık ilanını da kabul etmek istemedi. Gönderdiği notalar ile diğer devletlere bu durumun Berlin Antlaşması hükümlerine aykırı olduğu ve bu nedenle Bulgaristan'ın hukuki statüsünün tekrar sağlanması için uluslararası bir konferans toplanmasını istedi. Ancak Osmanlı Devletinin bu isteği pek bir karşılık bulmadı. Zira diğer devletler açısından Bosna-Hersek'in ilhakı ile ortaya çıkan durum daha büyük bir önem arz etmekteydi.

\footnotetext{
39 “Aynı yerde", s. 285.

${ }^{40}$ Kozmenko ve Konobeyev, a.g.m., s. 477.

${ }^{41}$ O. İ. Aganson, "Bolgariya v "Balkanskoy İgre" Velikobritanii v Naçale XX v.", Vestnik $R U D N$, ser. Vseobşaya İ́storiya, No 2, 2011, s. 80.

42 “Aynı yerde", s. 80-81.
} 


\section{ŞAHIN DOĞAN}

Bulgaristan Osmanlı Devleti’nin bağımsızlığını tanıması için Fransa'nın arabulucu olmasını istedi. Diğer taraftan İngiltere ise Osmanlı Devleti'nin savaş açma niyeti üzerine bazı tavizler karşılığında Bulgaristan'ın bağımsızlığını tanımasını tavsiye etti. Bu uluslararası konjöktürde Osmanlı Devleti 1908 yılı sonlarından itibaren Bulgaristan'ın bağımsızlığ karşısında alınacak tazminat hususunda Bulgaristan ile görüşmeler yapmaya başladı. Ancak bu görüşmeler çok uzadı ve hatta Bulgaristan'ın Osmanlı Devleti'nin belirlediği tazminatı kabul etmek istememesi nedeniyle her iki taraf savaş ihtimaline karşı askeri hazırlıklara başladı. Osmanlı-Bulgar ilişkilerinin böyle bir hal alması üzerine Şubat 1909 tarihinde Rusya bu duruma müdahale ederek tazminat konusunda Osmanlı Devleti ile Bulgaristan'ın anlaşmasını sağlamak üzere bu sürece dâhil oldu. ${ }^{43}$

Rus basınında yer alan dış politika değerlendirmelerinde, 1909 y1lı Şubat ayı içerisinde Rusya'nın Bulgaristan'ın bağımsızlığını ve Ferdinand'ın yeni unvanını fiilen tanıması ayrıca Avusturya-Osmanlı Antlaşması ve Rusya ile Osmanlı arasında Türk-Bulgar anlaşmazlığının giderilmesi için yapılan görüşmeler, önemli olayların başında yer almaktaydı ${ }^{44}$

Nitekim bu gelişmelerden ilki ile ilgili olarak Ferdinand'ın Knez Vlademir Aleksandroviç'in cenaze merasimi için Petersburg'a gitmesi ve Bulgaristan'ın başında olan Knez'in unvanı meselesinin çözülmesi büyük bir öneme sahipti ve bu durum Avrupa basınında da yapılan yorumlara bir canlılık getirmişti. Bu yorumlara göre, bu durum Berlin Antlaşmasının bozulması anlamına gelmekteydi. Ancak kısa bir zaman içerisinde Rusya'nın başka türlü davranamayacağı kabul edilmişti. Zira Rusya'nın Tırnova gelişmesini kabul etmemesi prensip gereği değildi, sadece bu gelişmenin şekline karşı bir protesto idi. Ayrıca bu uluslararası antlaşmayı bozan bir durumdu. Rus basınında yer alan değerlendirmeye göre, Rusya'nın bu mesele karşısındaki kararsızlığı Bulgar milli onuruna bir hakaret olurdu. Rusya kendi tarihsel geleneğine sadık kalarak farklı davranamazdı. Ayrıca Rus basınına göre bu durum Alman gazetelerinin belirttiği gibi İngiliz-Rus ilişkilerinin soğumasına da neden olmamışt1. ${ }^{45}$

\footnotetext{
${ }^{43}$ Fahir Armaoğlu, 19. Yüzyll Siyasi Tarihi (1789-1914), TTK Yay., Ankara, 2003, s. 626-627. Osmanlı Devleti'nin Bulgaristan'ın bağımsızlık ilanı karşısındaki tutumu ve bu husustaki gelişmeler hakkında daha geniş bilgi için Bkz.: Hasan Ünal, "Balkan Diplomasisinden Bir Kesit: Bulgaristan'ın Bağımsızlık İlanı ve Osmanlı Dış Politikası (1908-1909)”, Yeni Balkanlar Eski Sorunlar, Bağlam Yay., İstanbul, 1997, ss. 53-71.; Sarınay, a.g.m.

${ }^{44}$ L. Galberştadt, "İnostrannaya Politika”, Russkaya Misl, Mart 1909, s. 207.

45 “Aynı yerde".
} 


\section{RUS KAYNAKLARI IŞIĞINDA BULGARISTAN'IN BAĞIMSIZLIK ILANI}

Ancak bu süreç devam ederken İstanbul'da 13 Nisan 1909 (31 Mart 1325) günü 31 Mart Vakası patlak verdi. İstanbul'da yaşanan bu olayın devam eden Osmanlı-Bulgar görüşmelerine etkisi de kaçınılmazdı.

Nitekim Rusya'nın Sofya Büyükelçisi Sementovsky -Kurilo 13 Nisan (31 Mart) tarihli telgrafında, aldığı bilgilere göre İstanbul'da yaşanan askeri ayaklanma ile başlayan sürecin Bulgaristan için hala açı kalan bağımsızlığının tanınma meselesi nedeniyle galeyana neden olabileceğini bildirmekteydi. Gelişmeler üzerine Büyükelçi Malinov ile derhal görüşmek için harekete geçmiş ve Malinov'un oldukça endişeli olduğunu fark etmişti. Malinov, Ulusal Meclis seçimleri için taşrada bulunan bütün bakanları acele toplantıya çağırdı. Yapılacak bu toplantı ile ne yapılacağı kararlaştırılacaktı. Elçiye göre toplantıdan çıkacak kararın ılımlı olacağına veya Türklerin talebi nedeniyle son anda ertelenen bağımsızlık sorununa son vermek için hükümetin radikal önlemlere, özellikle genel seferberliğe meyilli olmayacağına garanti verilemezdi. O halde, durumdan yararlanmaktan daha çok, uzun süredir istenen barışı temin etmek için, St. Petersburg'da Paprikov tarafından imzalanan anlaşmanın yürürlükte kalması şartıyla elbette ki, Üçlü İtilaf Devletlerinin teşebbüsü ile Bulgaristan'ın bağımsızlığı hemen tanınmalıydı. Üstelik böyle bir adım, Yakın Doğuda öngörülen muhtemel olaylar ışığında, nüfuzlarının burada yüksekte tutulması adına da Üçlü İtilaf Devletlerinin faaliyet ortaklığının önemini artıracaktı. Fransız ve İngiliz temsilcileri de bu görüşü paylaşmaktaydılar. ${ }^{46}$

Osmanlı Devleti içerisinde yaşanan bu hadiseler belirsizlik yaratırken Büyük Devletleri de endişeye sürüklemişti. Nitekim Paris'e bir günlük ziyareti sırasında Kral Edward'la Fransız hükümeti arasında, Türkiye'deki olaylara daha yakın olmak için, Fransa ve İngiltere'nin her birinin Pire'ye iki kruvazör gönderecekleri anlaşmasına varılmıştır. Üçüncü bir Fransız kruvazörü ise Toulon'da hazır bekleyecektir. Kral, Rus Büyükelçi Nelidov’a Doğu'daki olaylardan endişeyle bahsetmekteydi. ${ }^{47}$

\footnotetext{
${ }^{46}$ Telegramma poslannika v Sofii ot 13 aprelya (31 mart) 1909 g. No-24 Der.: PAPOV, A. “Turetskaya Revolutsiya 1908-1909”, Krasniy Arhiv, T. 2 (45), Moskva 1931, s. 27-52, (Krasnıy Arhiv'in bu sayısında yayımlanmış olan belgeler dipnotlarda daha açıklayıcı olması nedeniyle belge isimleri ve numaraları ile verilmiştir.)

${ }^{47}$ Telegramma posla $v$ Parije ot 16 (3) aprelya $1909 \mathrm{~g}$. No:76.
} 


\section{ŞAHIN DOĞAN}

Diğer taraftan İngiliz savaş gemilerinin Çanakkale Boğazı yakınlarına geldiğini öğrenen Sadrazam, İngiliz Büyükelçisinden kendisine açıklama yapmasını istedi. Ancak Sir Gerard A. Lowther, Tevfik Paşa'nın bu isteğini yerine getiremediği için, Londra'daki Türk Büyükelçisine bu konuda İngiliz Dışişleri Bakan yardımcısına müracaat etmesi talimatı verildi. Sir Edward Grey'in Rus Büyükelçisine bildirdiğine göre İngiliz donanmasının Türkiye'ye yönelik komşuları tarafından herhangi bir düşmanca girişimi engellemek maksadıyla Türk sularında olduğunu söylemiştir. Aynı zamanda Sir Edward Grey, diğer amaçlarının ecnebi vatandaşların güvenliğini sağlamak olduğunu ama İngiliz hükümetinin buna gerek kalmayacağını ümit ettiğini bildirmişti. ${ }^{48}$

$\mathrm{Bu}$ gelişmeler üzerine İzvolskiy diğer Büyük Devletlerin savaş gemilerinin Türk sularında olması sebebiyle, üç hafta içinde Baltık donanmasından iki veya üç kruvazörün Akdeniz'in doğusuna gönderileceğini Rusya'nın İstanbul Büyükelçisine bildirdi. ${ }^{49}$

Büyük Devletler gibi Balkan Devletleri de Osmanlıdaki gelişmeler neticesinde bir an evvel bir strateji belirlemek üzere kendi aralarındaki diplomatik ilişkilere hız verdiler.

16 Nisan (3) ${ }^{50}$ tarihinde -karşıllklı çıkarları sağlamak üzere- birlikte hareket etmek için, Belgrad kabinesi Osmanlı Devleti'ndeki olaylarla ilgili Bulgar hükümeti ile görüş alışverişinde bulunmak istediğini Sırp elçisi aracılığıyla Malinov'a iletti. Bu husus ayrıca Milovanoviç tarafından Sirbistan'daki Bulgar temsilcisine de iletildi. Fakat Malinov, hükümetin dikkatleri bağımsızlığın tanınması konusuna yöneldiği için, şu anda bu konuyla ilgili bir şey söylemenin zor olduğu cevabını verdi. Ancak bununla beraber, daha ayrıntılı açıklama istediğini ve ortak faaliyet çıkarları ihtimali varsayılırsa Milovanoviç in Osmanlı Devleti içerisinde yaşanan bütün olaylar hakkındaki görüşlerini onunla paylaşmasını rica etti ve Geşov'a bununla ilgili talimat verildi. ${ }^{51}$

Bu dönemde Rusya'nın Bükreş Büyükelçisi olan Girs'in 17(4) Nisan 1909 tarihli telgrafında Romanya'nın söz konusu gelişmelere yaklaşımını

${ }^{48}$ Depeşa posla v Konstantinopole ot 21 (8) 1909 g. No:75.

${ }^{49}$ Telegramma inostrannix del poslu $v$ Konstantinopole ot 23(10) aprelya 1909 g. No:684.

${ }^{50}$ Rusların kullandıkları eski takvim ile Miladi takvim arasında 13 günlük fark bulunmaktadır. Çalışmamızda parantez içerisinde verilen tarihler belgelerde kullanılan eski takvime göredir.

${ }^{51}$ Telegramma poslannika $v$ Sofii ot 16 (3) aprelya 1909 g. No:26. 


\section{RUS KAYNAKLARI IŞIĞINDA BULGARISTAN'IN BAĞIMSIZLIK İLANI}

anlatırken Meclis başkanı ile yaptığı özel bir konuşmada kendisine, Bratianu'nun Rus hariciye nazırı yardımcısı Çarıkov'un Romanya elçisine İstanbul'daki olaylardan bahsederken, Rusya'nın bu olaylara sakin baktığını ve yerel problemlerle uğraşmayacağını belirtmekle birlikte onun ise gelişmelerden dolayı çok endişe duyduğunu ve Bulgaristan'ın Osmanlı Devleti'ne saldırması durumunda Doğu meselesinin büyüyeceğinden korktuğunu belirtmişti. Fakat, Romanya'da Sofya'dan böyle bir saldırının kaçınılmazlığı hakkında malumat alınmamıştı ve Büyükelçinin verdiği bilgilere göre Romanya, Bulgaristan'ın bağımsızlığına saygı duyuyor, ancak topraklarının büyümesini kabul etmemekteydi. Bratianu, müdahale etmeme politikasını değiştirmek ve Balkan sorununun çözümünü Avrupa'ya bırakmak için hiçbir neden görmüyordu. Ayrıca herhangi bir askeri önlemi de kabul etmemekteydi. Ancak Bulgaristan'ın kendi lehine sınırları gerçekten değiştirmeyi hedeflediğinden emin olursa, Romanya, Bulgaristan'1 bir anlaşma yapmaya zorlamak için derhal ordusunu seferber edecekti. ${ }^{52}$

Rus Dışişleri Bakanı İzvolskiy Belgrad Büyükelçisi’ne çektiği 18 (5) Nisan tarihli Telgrafında kendilerinin Bulgaristan ile Sırbistan arasındaki yakınlaşmaya ve Slavların ortak çıarlarına tehlike arz edecek anlaşmazlıklardan kaçınmak için müşterek faaliyetlerine her zaman içtenlikle sempati duyduklarını ifade etmekteydi. Bakan Telgrafta Bulgar-Sırp yakınlaşması ile ilgili, Petersburg'da bulunan Paprikov'la düşüncelerini paylaştığını ve Paprikov'un da kendisini Bulgarların da Sırbistan ile dayanışma içinde olma arzusunun varlığına ikna ettiğini belirtmekteydi. Nitekim, İzvolskiy, Sementovski ye Sofya'ya döndüğünde Paprikov'un meselesi ile ilgilenmesi talimatı vermişti. ${ }^{53}$

İzvolskiy telgrafinda Büyükelçiye Osmanlı Devleti'nde yaklaşan kriz sırasında, Sırp hükümetinin tamamen soğukkanlılık göstermesi gerektiği arzusunu ifade diyordu. Özellikle Surbistan'ın kendi faaliyetleri ve Bulgaristan'la dikkatsiz müzakereleriyle, Avusturya'ya Osmanlı Devleti'ndeki krize aktif olarak müdahale etmesi için bir neden oluşturmaması gerektiğini belirtmekteydi. ${ }^{54}$

\footnotetext{
${ }^{52}$ Telegramma poslannika $v$ Buxareste ot 17 (4) aprelya $1909 \mathrm{~g}$.

53 Telegramma ministra inostrannix del poslanniku v Belgrade ot 18 (5) aprelya $1909 \mathrm{~g}$. No:594.

${ }^{54}$ Telegramma ministra inostrannıx del poslanniku v Belgrade ot 18 (5) aprelya $1909 \mathrm{~g}$. No:594.
} 


\section{ŞAHIN DOĞAN}

Bu gelişmeler yaşanırken Rusya'nın araya girmesi ile başlayan süreç 19 Nisan 1909 tarihinde iki anlaşma ${ }^{55}$ ile sonuçlandı. Nitekim, Bulgaristan Rusya'nın anlaşma teklifini kabul etti. İstanbul da bu teklifi kabul etmek durumunda kaldı. 16 Mart 1909 tarihinde finans meselesine ilişkin bir protokol imzaland1. 19 Nisan'da ise Bulgaristan'ın resmi temsilcisi Ticaret Bakanı Andrey Lyapçev İstanbul'da Türk-Bulgar protokolünü imzalad1. ${ }^{56} \mathrm{Bu}$ anlaşmalar neticesinde Osmanlı Devleti Bulgaristan'ın bağımsızlığını tanıdı. Böylece II. Meşrutiyetin ilanı Bosna-Hersek gibi Bulgaristan'ın da elden çıkması ile sonuçland $1{ }^{57}$ Aynı gün Petersburg'da Rus-Bulgar protokolü imzalandı. Buna göre Bulgaristan Rusya'ya 75 yıl boyunca 82 Milyon Frank ödeyecekti. Ancak Bulgaristan, bu borcun ancak 11,33 milyon Frank'ını ödemiş, 1917 ihtilalinden sonra Bolşevikler Çarlık Rusya'nın bütün borç ve alacaklarını sildikleri için geri kalan borcu ödememiştir. ${ }^{58}$

Yapılan bu antlaşmaların ardından Rus basınında yer alan değerlendirmeye göre, Osmanlı-Avusturya antlaşmasının imzalanması ve Osmanlı ile Bulgaristan arasında aracı olan Rusya'nın Osmanlıyla gelişen ilişkileri Avrupa'nın bu bölgesinde bulutların dağılmasını sağlamıştı. Ayrıca Osmanlının yeni Hariciye nazırının Petersburg'a gelişi özellikle "Balkan Federasyonu" planları için iyimser olmalarına neden olmuştu. Yine bu değerlendirmede Rusya'nın Bulgaristan ve Osmanlıya ilişkin attığı son adımlar Rusya'nın Bulgar-Sırp yakınlaşması adımlarına benzetiliyor ve yapılan bu hamle Balkan Federasyonu projesinin bir adımı olarak görülüyordu. ${ }^{59}$

Elbette ki Rusya'nın bu sürece dâhil olması bir rastlantı değildi zira Rusya'nın bu sürece dâhil olması İngiltere ve Rusya'nın Balkanlarda izledikleri politikanın bir tezahürü idi. Nitekim İngiltere ve Rusya çok iyi biliyorlardı ki Bulgaristan'ın merkezi devletler tarafına geçmesi Balkanlarda güç dengesini Avusturya-Alman bloku lehine çevirecekti. Çünkü sadece Sırbistan tek başına Avusturya-Macaristan'ın baskılarına karşı koyamazdı. ${ }^{60}$

\footnotetext{
${ }^{55} \mathrm{Bu}$ anlaşmalar hakkında bkz. Kozmenko ve Konobeyev, a.g.m., s. 478.

${ }^{56}$ Çervenkov ve Şkundin, a.g.m., s. 34.

${ }^{57}$ Armaoğlu, a.g.e., s. 626-627.

${ }^{58}$ Çervenkov ve Şkundin, a.g.m., s. 34.

${ }^{59}$ L. Galberştadt, "İnostrannaya Politika", Russkaya Mısl, Mart 1909, s. 207.

${ }^{60}$ Daha sonra gelişen Avusturya-Sırbistan anlaşmazlığı hakkında "Russkaya Mısl” dergisi hariciye yazarı L. Galberştadt, derginin 1909 Mart sayısında çıkan oldukça detaylı ve ilgi çekici analizleri için Bkz. L. Galberştadt "İnostrannaya Politika", Russkaya Mısl, Mart 1909, s. 191207.
} 


\section{RUS KAYNAKLARI IŞIĞINDA BULGARISTAN'IN BAĞIMSIZLIK İLANI}

Dolayısıyla bu koşullar altında bu stratejik bölgede Bulgaristan'ın Alman blokuna kayması İngiltere ve Rusya için büyük bir tehdit olarak görülmekte ve bu nedenle Bulgaristan'ın "Üçlü Anlaşma” Devletleri tarafına çekilmesi zaruri olarak görülmekteydi. Özellikle Rus Dışişleri Bakanı A. P. İzvolskiy'in bu husustaki çabaları olumlu sonuçlar doğurmuş ve yukarıda belirtildiği üzere Osmanlı Devleti ile Bulgaristan arasında devam eden tazminat meselesinin çözümüne dâhil olarak Bulgaristan'1 büyük bir yükten kurtarmıştı. Zira yukarıda belirtildiği üzere Rusya 93 Harbi sonrası Osmanlı Devleti'nden alacağı olan tazminattan vazgeçerek bunu Bulgaristan'ın vereceği tazminat yerine saydırdı. Nitekim Bulgaristan'nın Osmanlı Devleti'ne bağımsızlık için ödemek zorunda olduğu 125 milyon Frank tazminat, Osmanlı Devleti'nin Berlin Antlaşması ile Rusya'ya ödemesi gereken ancak henüz ödemediği 125 milyon Frank borca sayıldı. Diğer taraftan ise Petersburg'da bu bedel karşı1lığında Bulgaristan'a çok düşük faiz ile kredi verilerek bu mesele halledildi. ${ }^{61}$

Yukarıda söz konusu edilen, İzvolskiy'in Osmanlı Devleti'nde yaşanan olaylarla ilgili dayanışma kurması için Sırp hükümetinin Bulgaristan'la müzakerelerde son derece dikkatli davranması gerektiğine ilişkin telgrafının içeriği Milovanoviç'e gizlice iletildi. Milovanoviç İzvolskiy'in talimatlarını yerine getirmeye tamamen hazır olduğunu ifade etti. Bakan aynı zamanda, Rusya'nın Bulgaristan'ın bağımsızlığını ne zaman tanıyacağı hakkında Belgrad kabinesini önceden haberdar etmesini rica ettiğini Rus Büyükelçisinden hükümetine iletmesini istedi. Nitekim Milovanoviç Bulgaristan'ın bağımsızlığını Sırbistan'ın Rusya ile aynı zamanda ya da Rus hükümeti uygun bulursa Rusya'dan kısa zaman önce tanıması gerektiğini Rus yetkililere bildirdi. Milovanoviç'e göre, Sırp hükümetinin Bulgaristan'a karşı böylesi dostane bir hareketi, iki Slav ülkesini yakınlaştırmak ve aralarında samimi komşuluk ilişkileri kurmakta son derece önemli olabilirdi. ${ }^{62}$

Ancak bununla birlikte Rus diplomatları bölgedeki bu gelişmelerin ardından askeri hareketlilik ihtimali üzerinde de durmaktaydılar. Nitekim Rusya'nın Bulgaristan'daki askeri ataşesi Leontiev'in 20 (7) 1909 tarihli raporundan anlaşıldığı üzere bölgedeki gelişmeler gerginleşmeye başlarsa, büyük ihtimalle bölgedeki ülkelerde gizlilik nedeniyle seferberliği aynı anda gerçekleştirmek mümkün olamayacak ve kesinlikle Bulgaristan'da diğer

${ }^{61}$ Aganson, a.g.m., s. 81.; Armaoğlu, a.g.e., s. 627.

${ }^{62}$ Telegramma poverennogo $v$ delax v Belgrade ot 20 (7) aprelya 1909 g. No:155. 


\section{ŞAHIN DOĞAN}

ülkelerden sonra seferberlik gerçekleşebilecekti. Bu nedenle Leontiev konuyla ilgili olarak Rus elçisinden bütün konsolosları uyarmasını rica ediyordu. Rus Ataşenin verdiği bilgilere göre başta Avusturyalı ataşe olmak üzere yabanc1 ataşeler gergindi. Nitekim Sırp ataşesi de kendisine, Bulgaristan'ın harekete geçmesi durumunda, Sırbistan'ın, Avusturya'nın buna nasıl tepki vereceğine bakmadan aynısını yapacağı konusundaki görüşünü açıklamıştı. ${ }^{63}$

Rus Dışişleri Bakanı İzvolski'in Belgrad ve Sofya Büyükelçiliklerine gönderdiği 23 (10) Nisan 1909 tarihli telgrafta da gizli ve güvenilir bir kaynağa göre, Baron Erenthal Viyana'da olan Enver Bey'e, Bulgaristan ve Sırbistan'ın mevcut şartlarda Osmanlı Devleti'ne karşı tehlike oluşturduğu takdirde Avusturya'nın hemen harekete geçeceği teminatını verdiğini bildirmekteydi. $\mathrm{Bu}$ nedenle İzvolskiy, büyükelçilerin görevde oldukları ülkedeki hükümetleri bu konuda tedbir almaya ikna etmeyi dikkatten kaçırmamalarını istemekteydi. ${ }^{64}$

Rusya'nın Bükreş Büyükelçisi M. Girs'in 27(14) Nisan 1909 tarihli raporunda belirtildiği üzere Bükreş'deki Bulgar temsilcilerin gerginliklerine bakılırsa, Sofya hükümeti, Osmanlı İmparatorluğu ile olası ilişkilerin ne şekilde gelişeceğini anlamak hususuyla çok ilgiliydiler. Nitekim Girs'i ziyaret eden Bulgar temsilcisi Albay Hesaçiyev, kendisinin Bratianu ile olan konuşmasını güvenilir bir kaynaktan öğrendiğini söylemiş ve 4 ve 5 Nisan tarihlerinde İzvolskiy'e gönderdiği telgrafların içeriğini kelimesi kelimesine anlattıktan sonra Bulgaristan'a baskı yapmaları için Romen hükümetinin Büyük Devletlere yardım teklif edip etmediğini öğrenmeye çalışmıştı. Ayrıca, rapor vermesi için acele Sofya'ya çağrılan Bulgar ataşesi Stanchov Romanya'nın Bulgaristan'a olan tutumunu öğrenmek için Girs'i ziyaret etmişti. Girs ise Bulgar meslektaşının ihtiyatlı davranmasından şüphelenmekteydi. Girs hem Bulgar temsilcisi Albay Hesaçiyev'e hem de Stanchov'a son zamanlarda Romanya'nın Bulgaristan'a yönelik tutumunda herhangi bir değişiklik olmadığı inancını iletmişti. Zira Girs'e göre eskiden de olduğu gibi Romanya şu anda, Balkan politikasını büyük güçlerin çıkarları ile birleştirmek için uğraşıyordu ve şüphesiz bu politikada etkili bir rol oynayabilirse son derece memnun olacaktı. Aynı zamanda Romanya, Bulgaristan ile dostça ilişkiler kurmanın yararlarını anlayarak bütün

\footnotetext{
${ }^{63}$ Donoseniye voennogo agenta v Bolgarii ot 20 (7) aprelya 1909 g. No:82.

${ }^{64}$ Telegramma ministra inostrannix del poslannikamw v Belgrade i Sofii ot 23(10) aprelya 1909 g. No:673.
} 


\section{RUS KAYNAKLARI IŞIĞINDA BULGARISTAN'IN BAĞIMSIZLIK İLANI}

vasıtalarla onları destekleyecektir, ancak aralarındaki denge şimdilik bozulmayacaktır. Fakat Büyükelçinin verdiği bilgiye göre, Romanya Bulgaristan'ın Balkan olaylarından istifade ederek arazisini genişletmek niyetlerini görürse, dengeleri yeniden eşitlemek için zaman kaybetmeden seferberlik ilan ederek Bulgarları kendileri ile anlaşmaya varmaya mecbur edecektir. Bu adımın büyük güçler tarafından nasıl karşılanacağına bile önem vermeyecektir. ${ }^{65}$

Yukarıda ifade edilen Rus diplomatların faaliyetlerinden de açıç̧a anlaşıldığ1 üzere Rusya Bulgaristan'ın bağımsızlığını ilanı sonrasında da Balkan Devletleri arasında etkin bir rol oynamaya ve bu Devletleri arzu ettiği siyasi yönde kanalize etmeye devam edecektir. Nitekim izlenen bu politikalar, bölgedeki sorunlar ve diğer Büyük Devletlerin siyasetleri, Balkan Devletleri arasındaki anlaşmazlıklar bölgedeki siyasi gelişmeleri kısa bir süre sonra Balkan Savaşlarına evrimleştirecektir.

Hâlbuki 1909 yılında Rus basınının değerlendirmesine göre Bulgaristan'ın son yıllarda izlediği ikili politika, Berlin diplomatlarının Balkanlar'da suyu bulandırması için imkân sunması hususunda düşündürmekte ise de Üçlü Anlaşma Devletlerinin Balkanlar'da asayişi sağlayacağı ümit edilmekteydi. ${ }^{66}$ Ancak bölgedeki siyasi gelişmeler bunun böyle olmadığını kısa bir süre sonra gösterecektir.

\section{Sonuç}

Elimizdeki Rus diplomatik yazışmalarını değerlendirdiğimizde, özellikle Temmuz ihtilalinin ardından oluşan belirsizliğin ve iktidara gelen İttihad ve Terakki'nin Balkan Devletleri ve Bulgaristan yetkililerini kaygılandırdığını ve oluşan mevcut koşullarda yeni bir siyaset belirlemek için büyük bir diplomatik çaba harcadıklarını görüyoruz. Bu ortam içerisinde Rus diplomatlar ise başta Slav Devletleri olmak üzere Balkan Devletlerini ortak hareket ettirme yönündeki çabaları açık bir şekilde görülmektedir.

Sonuç olarak Osmanlı Devleti'nde yaşanan Jön Türk ihtilali ve akabinde gerçekleşen 31 Mart vakası neticesinde Bulgaristan'ın Osmanlı Devleti'nden ayrılması için koşullar oluşmuş oldu ve Bulgaristan bu durumu

${ }^{65}$ Depeşa poslannika v Buxareste ot 27(14) aprelya 1909 g. No: 32.

${ }^{66}$ L. Galberştadt, “İnostrannaya Politika”, Russkaya Mısl, Eylül 1908, s. 206. 


\section{ŞAHIN DOĞAN}

iyi değerlendirerek bağımsızlığını ilan etti. Her ne kadar Bulgar Hükümeti Osmanlı'da kurulan yeni rejimi kendileri açısından büyük Bulgaristan'1 kurma planı açısından tehlikeli bularak Jön Türklere karşı tavır almış olsalar da sonuç itibariyle Geşov'un: "Eğger Jön Türk İhtilalinden bir şeyler kaybedeceksek o vakit bu bir şekilde tazmin edilmelidir. Bu bugün için Bulgaristan'ın tam bağımsızlı̆̆ dışında başka bir şey olamaz." Sözleri ile anlatılan tezi gerçekleştirilmiş oldu. Bulgaristan'ın bağımsızlık ilanından sonra ise Rusya başta olmak üzere Büyük Devletlerin izledikleri siyaset, bir başka deyişle Büyük Devletler arasındaki çıkar çekişmelerinin Balkanlara yansıması ve Balkan Devletleri arasındaki sorunlar Balkan Savaşları için ortam sağlamış oldu.

Nitekim hem Rusya hem de diğer Büyük Devletlerin izledikleri bu politikalar, bölgede sürekli olarak ortaya çıkan yeni sorunlar, Balkan Devletleri arasındaki anlaşmazlıklar bölgedeki siyasi gelişmeleri kısa bir süre sonra Balkan Savaşlarına evrimleşmesine ve Balkan topraklarının Osmanlı hâkimiyetinden tamamen çıkmasıyla sonuçlandı.

Yukarıda da belirtildiği üzere makalenin konusunu ihtiva eden Bulgaristan ve genel olarak Balkanlara ilişkin siyasi tarih araştırmalarında başta Rus arşivleri olmak üzere Rus kaynaklarının katkısının devam ettirilmesinin önemli bir perspektife sahip olduğunu belirtmek gerekir.

\section{KAYNAKÇA}

\section{Yayımlanmıș Belgeler}

PAPOV, A. "Turetskaya Revolutsiya 1908-1909”, Krasnıy Arhiv, T. 1 (44), Moskva 1931.

, “Turetskaya Revolutsiya 1908-1909”, Krasniy Arhiv, T. 2 (45),

Moskva 1931, ss. 27-52.

Raport voennogo agenta $v$ Bolgarii ot 21(8) avgusta $1908 \mathrm{~g}$. No:143.

Telegramma poslannika $v$ Sofii ot 13 aprelya (31 mart) 1909 g. No-24.

Telegramma posla v Parije ot 16 (3) aprelya $1909 \mathrm{~g}$. No:76.

Depeşa posla v Konstantinopole ot 21 (8) $1909 \mathrm{~g}$. No:75.

Telegramma inostrannix del poslu $v$ Konstantinopole ot 23(10) aprelya 1909 g. No:684. 


\section{RUS KAYNAKLARI IŞIĞINDA BULGARISTAN'IN BAĞIMSIZLIK ILLANI}

Telegramma poslannika v Sofii ot 16 (3) aprelya 1909 g. No:26.

Telegramma poslannika $v$ Buxareste ot 17 (4) aprelya $1909 \mathrm{~g}$.

Telegramma ministra inostrannix del poslanniku v Belgrade ot 18 (5) aprelya 1909 g. No:594.

Telegramma ministra inostrannıx del poslanniku v Belgrade ot 18 (5) aprelya 1909 g. No:594

Telegramma poverennogo $v$ delax $v$ Belgrade ot 20 (7) aprelya $1909 \mathrm{~g}$. No:155.

Donoseniye voennogo agenta v Bolgarii ot 20 (7) aprelya 1909 g. No:82.

Telegramma ministra inostrannix del poslannikamw v Belgrade $i$ Sofii ot 23(10) aprelya $1909 \mathrm{~g}$. No:673.

Depeşa poslannika v Buxareste ot 27(14) aprelya 1909 g. No: 32.

Rus Genelkurmay Belgelerinde II. Abdülhamid ve Ordusu, (Yayına Hazırlayanlar: Mikhail Bashanov-İlyas Kemaloğlu), Zeytinburnu Belediyesi Kültür Yayınları, İstanbul 2018.

\section{Gazete ve Dergiler}

GALBERŞTADT, L., “İnostrannaya Politika”, Russkaya Mısl, Eylül 1908. “İnostrannaya Politika”, Russkaya Misl, Mart 1909.

\section{Kitap ve Makaleler}

ADANIR, Fikret, Makedonya Sorunu, Tarih Vakfı Yurt Yay., İstanbul 1996.

AGANSON, O. İ., "Bolgariya v "Balkanskoy İgre" Velikobritanii v Naçale XX v.”, Vestnik RUDN, ser. Vseobşaya İstoriya, No 2, Moskva 2011, ss. 72 86.

ARMAOĞLU, Fahir, 19. Yüzyll Siyasi Tarihi (1789-1914), TTK Yay., Ankara 2003.

AVCI, Yasemin, "Bağımsız Bulgaristan ile Osmanlı Devleti Arasında Modern Diplomasi (1908-1912)", Uluslararasl Osmanll ve Cumhuriyet Dönemi Türk-Bulgar İlişkileri Sempozyumu 11-13 Mayıs 2005 Bildiriler Kitabı, Eskişehir, ss. 291-297.

AYDIN, Mahir, Osmanlı Eyaletinden Üçüncü Bulgar Çarlı̆̆ına, Kitabevi Yay., İstanbul 1996. 


\section{ŞAHIN DOĞAN}

AYDIN, Mithat "Bulgaristan Yol Ayrımında: İvan S. Geşov Meselesi", Belleten, C.7, S. 280, Ankara 2013, ss. 1071-1102.

BAY, Serdar, Ikdam ve Tanin Gazetelerine göre Bulgaristan'ın Bağımsızlı̆gı (1908-1909), Kafkas Üniversitesi Sosyal Bilimler Enstitüsü, Yayımlanmamış Yüksek Lisans Tezi, Danışman: Doç. Dr. Oktay Kızılkaya, Kars 2016.

ÇERVENKOV, N.N. ve ŞKUNDİN, G. D., "Provozglaşeniye Nizavisimosti i obyavleniye Bolgarii Çarsrtvam", Bolgariya v XX Veke Oçerki Politiçeskoy Istorii, Nauka, Moskva 2003, ss. 29-35.

ÇETIN, Erol, Bulgaristan Prensliği ile Osmanl İmparatorluğu Arasındaki Siyasi İişkkiler (1878-1908), İstanbul Üniversitesi Sosyal Bilimler Enstitüsü, Yayımlanmamış Doktora Tezi, Danışman: Prof. Dr. Toktamış Ateş, İstanbul 2003.

HACISALİHOĞLU, Mehmet "İttihatçılar ve Makedonya İhtilal Komiteleri: İttihad ve Terakki Hükümetinin Başlamasına Kadar İlşkiler, Pazarlıklar ve Sonuçları", İstanbul Ünv. Edebiyat Fakültesi Tarih Dergisi, No: 38, İstanbul 2002, ss. 101-117.

JELAVICH, Barbara, Balkan Tarihi 18. Ve 19. Yüzyıllar, C.I-II, Çev.: İhsan Durdu, Haşim Koç, Gülçin Koç, Küre Yay., İstanbul 2006.

KARAL, Enver Ziya, Osmanlı Tarihi (İkinci Meşrutiyet ve Birinci Dünya Savaşı), C. V, TTK Yay. (basım yeri ve yılı belirtilmemiş)

KOZMENKO, İ. V. ve KONOBEYEV, V. D., "Aktivizisatsiya vneşney Politiki Bolgarskoy burjuazii v naçale XX v.", İstoriya Bolgarii, AN SSSR, T.I, Moskva 1954, ss. 473-480.

LITAVRIN, G.G., Kratkaya İstoriya Bolgarii s Drevneyş̧ih Vremen do Naşih Dney, İzd: Nauka, Moskva 1987.

SAATÇİ, Meltem Begüm, Makedonya Sorunu (1903-1913), Akdeniz Üniversitesi. Sosyal Bilimler Enstitüsü, Yayımlanmamış Doktora Tezi, Danışman: Prof. Dr. İsrafil Kurtcephe, Antalya 2004. 


\section{RUS KAYNAKLARI IŞIĞINDA BULGARISTAN'IN BAĞIMSIZLIK İLANI}

SARINAY, Yusuf, “Osmanlı Devleti'nin Bulgaristan'ın Bağımsızlığını Tanınması ve Türk-Bulgar İlişkilerinin Gelişmesi”, Uluslararası Osmanlı ve Cumhuriyet Dönemi Türk-Bulgar İlişkileri Sempozyumu 11-13 Mayıs 2005 Bildiriler Kitabı, Eskişehir, ss. 133-138.

SKVOZNIKOV, Aleksandr Nikolayeviç, Makedonskiy Vopros vo Vneşney Politike Rossii v Naçale XX veka (1903-1908), Samarskiy GPU Avtoreferat, Nauçnıy Rukovoditel: Anşakov Yuriy Petroviç, Samara 2006.

"Rossiyskaya Diplomatiya o Putyah Reşeniya Makedonskoy Problemı v Kontse XIX- Naçale XX Veka", İzvestiya Somarskogo Nauçnogo Sentra RAN, T. 12, No: 2, Samara 2010, ss. 82-86.

"Makedonskiy Vopros v Naçele XX Veka i Rossiyskaya Obşestvennost", İzvestiya Somarskogo Nauçnogo Sentra RAN, T. 11, No: 2, Samara 2009, ss. 70-76.

TAŞÇAN, Arzu, Bulgaristan 'ın Bağımsızlık Sürecinde Kilisenin Fonksiyonel Rolü, Dokuz Eylül Üniversitesi Sosyal Bilimler Enstitüsü, Yayımlanmamış Doktora Tezi, Danışman: Prof. Dr. Mehmet Şeker, İzmir 2011.

TOKAY, Gül, Makedonya Sorunu ve Jön Türk İhtilalinin Kökenleri 19031908, Afa yay., İstanbul 1995.

TOPRAK, Serap “Bulgaristan'ın Bağımsızlığında Rusya'nın Rolü”, History Studies Uluslararası Tarih Araştırmaları Dergisi, V. cilt, 6. sayı [Balkan Savaşları Özel Sayıs1], Samsun 2013, ss. 131-147.

ÜNAL, Hasan, “Balkan Diplomasisinden Bir Kesit: Bulgaristan'1n Bağımsızlık İlanı ve Osmanlı Dış Politikası (1908-1909)”, Yeni Balkanlar Eski Sorunlar, Bağlam Yay., İstanbul 1997, ss. 53-71.

VATANSEVER, Erhan, Bulgar Milliyetçiliğinin Doğuşu ve Bulgaristan'in Bağımsızlı̆̆ (1841-1908), Trakya Üniversitesi Sosyal Bilimler Enstitüsü, Yayımlanmamış Doktora Tezi, Danışman: Dr. Öğr. Üyesi Sabri Can Sannav, Edirne 2019. 